\title{
A methodology for assessing the pressures on transboundary groundwater quantity and quality - experiences from the Dinaric karst
}

\author{
Zoran Stevanović* \& Veljko Marinović ${ }^{1}$ \\ ${ }^{1}$ University of Belgrade - Faculty of Mining and Geology, Centre for Karst Hydrogeology, Department of Hydrogeology, Djušina 7, 11000 Belgrade, Serbia; \\ (*corresponding author: zstev_2000@yahoo.co.uk)
}

doi: $10.4154 / g c .2020 .08$

\author{
Article history: \\ Manuscript received January 24, 2020 \\ Revised manuscript accepted May 13, 2020 \\ Available online June 29, 2020
}

\begin{abstract}
A relatively novel and abridged methodology for assessing the quantity and quality status of groundwater bodies has been applied in the Dinaric karst of SE Europe. Validation of pressure on quantity is based on groundwater budgeting and the correlation of available groundwater reserves and projected water demands, while pressure on quality is estimated by GIS-created maps: vulnerability - hazard - risk. The results obtained from the studied groundwater bodies indicate mostly low pressure on water quantity, but increased risk from diffuse and point pollution sources. The application of methods is possible in many transboundary and inner aquifer systems even in geologically complex environments where there is insufficient monitoring data on the groundwater regime.
\end{abstract}

Keywords: transboundary aquifer, karst, vulnerability, hazard, risk, Dinaric region
The study area is a "classical" Dinaric system (Dinarides), an elongate, south European orogenic belt of the Alpine mountain chain (Alpides), oriented NW - SE and running parallel to the Adriatic Sea. The system, in which the presence of soluble carbonate rocks - karst happens to be dominant, extends from the Carso area in Italy through the countries of the former Yugoslavia (Slovenia, Croatia, Bosnia and Herzegovina, Montenegro, Serbia, North Macedonia), ending in the Albanian Alps (STEVANOVIĆ et al., 2016). That is the region where a new scientific discipline - karstology was born as a result of studies by Jovan Cvijić (1893). Later works on the Dinaric karst by HERAK (1972), MIJATOVIĆ (1984), BONACCI (1987, 2014), MILANOVIĆ (2005) and many other authors helped to better understand the complex groundwater distribution in this “classical” highly developed karst, one of the world's largest (FORD \& WILLIAMS, 2007). In the last decade, the current authors have completed several projects and studies in the Dinaric Region of SE Europe for the purpose of preparing a basis for RBMPs or improving groundwater monitoring (STEVANOVIĆ \& DOKMANOVIĆ, 2015; STEVANOVIĆ et al., 2015; STEVANOVIĆ \& MARINOVIĆ, 2016). This article is an attempt to present previously unpublished results on a relatively simple and technically unpretentious methodology for groundwater assessment especially in complex karst terrains. The idea was to enable water managers and practitioners in the countries undergoing the EU accession process, such as Bosnia \& Herzegovina, Serbia or Montenegro, to better understand the functionality of aquifer systems and facilitate the implementation of EU WFD. Although the methodology is primarily developed for transboundary aquifers, such as those that were prioritised in the preparation of RBMPs, the same approach can also be applied to inner aquifer systems.

\section{MATERIALS AND METHODS}

While in many countries of the world groundwater happens to be something that is 'out of sight, out of mind', the EU is definitely the world's leader in recognising the importance and defining/implementing a strategy for its sustainable development. The WFD provides general guidelines for delineation and characterisation of geologically complex and heterogenous systems such as karst. 
groundwater bodies (GWB as the management unit), and for monitoring water quality and quantity. The "Daughter" Groundwater Directive (2006/118/EC) (EC, 2006), on the other hand, sets out criteria for assessing the chemical status of groundwater, as required by Article 17.2a of the WFD. Given that EU Member States are characterised by different geology and hydrogeology, and consequently by varying water quality, a set of additional documents - the Common Implementation Strategy (CIS) for the Water Framework Directive - was prepared with the aim of establishing the common criteria and approach in the process of characterisation and assessment of groundwater bodies throughout Europe (EC, 2007, 2009). However, it is also true that a framework package allows much flexibility, as well as the adaptation of required GWB status assessments to the local circumstances and specificities. For instance, the concept that each GWB that supplies more than 50 people and where the abstraction is larger than $10 \mathrm{~m}^{3} /$ day should be studied and monitored is impracticable in the countries of SE Europe. If such a criterion was to be deliberately applied, thousands of groundwater bodies would have had to be delineated in certain groundwater-rich countries, such those in the Dinaric Region. Therefore, at the country level, or at the level of large or medium river basins, delineation of GWBs with considerable surface or their grouping represents a more feasible solution for the characterisation process than studying each small unit separately.

In the last few decades, Geographical Information Systems (GIS) have been increasingly used in the geosciences (BEDELL, 1995; CHANG, 2008; WORBOYS \& DUCKHAM, 2004). A combination of remote sensing and the existing topographic, geological, pedological, land use and other maps makes it possible to obtain general information about the terrain and its characteristics and facilitate the creation of hydrological and hydrogeological models and water resources management (MILANOVIĆ et al., 2010). Putting all the information that was collected in such a way together with the data obtained from additional field surveys contained in the GIS database offers a great opportunity for various additional analyses that could be performed at a regional scale by mighty GIS extensions. Along with geospatial data, the data on groundwater quantity and quality deposited in specially designed water information systems (WIS) enable easy data manipulation, decision making, reporting and public participation in water management (ESRI Inc. 2003; WISE GIS, 2016). As suggested by the Global water partnership and International network of basin organizations (GWB/INBO) (GWB/INBO 2012), the development of coherent and integrated water resource management, as well as WIS as its essential tool, is fundamental if we wish to ensure sustainable water resources and appropriate socioeconomic development. WIS validated data must constitute an objective basis for discussion, negotiation, decision-making and assessment of the actions taken. The methodology for the assessment of status and pressures on groundwater which was used in several of the aforementioned regional and transboundary projects carried out in Dinaric karst is in fact the modified and further developed approach of WFD, with GIS as the main explanatory tool. Also, the grouping of GWBs was applied deliberately.

\subsection{Methods for Assessing Pressure on Groundwater Quantity}

The parameters of risk assessment of the quantitative status are either the groundwater level or the estimated water budget (bal- ance) of the groundwater body. According to Annex V, item 2.1.1 of the WFD, good quantitative status is identified when the groundwater level in the groundwater body is such that available groundwater resources are not exceeded by the long-term annual average rate of extraction. This is a highly relative assessment that does not consider exact values, which is therefore sometimes understood by decision makers from the water or ecology sectors quite restrictively; namely that exploitation of groundwater is limited, and there is a requirement that it be completely covered by recharge throughout the entire period of water extraction. This could mean that no depletion in the aquifer would be allowed, not even for a short period of time. The other, more "flexible" concept allows only temporary depletion and fast compensation for extracted waters. The issue of allowed water exploitation rate is closely linked with the "safe yield" concept, which was imposed for the first time by MEINZER (1920). The recent and - we could say - modern approach was introduced by CUSTODIO (1992), MARGAT (1992), BURKE \& MOENCH (2000) and several other hydrogeologists. Over-abstraction should not be defined in terms of variation of water table and its temporary depletion within an aquifer system, especially one that is as dynamic as that of a karst aquifer. Estimation of over-abstraction can be much more reliable if a multiannual balance is used, and the ratio between recharge and abstraction should be evaluated over many years instead of just one or no more than a few (BURKE \& MOENCH, 2000; STEVANOVIĆ, 2015).

In situations when monitoring of the groundwater regime is not systematically applied and does not cover all aquifer systems as in the case of the Dinaric karst, the water budget (balance) assessment is a more feasible option than water level observation when evaluating the quantitative pressure on GWBs. At the global scale, there are several initiatives - such as the activities of the UNESCO-IHP programme - that are aimed at developing water resources assessments and water budgets. The Atlas of World Water Resources was developed as part of this programme back in the 1970s, including guidelines for conducting water resources assessment. MARGAT \& VAN DER GUN published their work entitled Groundwater around the World (2013), which included groundwater budgeting, and FAO/AQUASTAT ${ }^{1}$ and the World Meteorological Organisation's (WMO) Commission for Hydro$\log ^{2}(\mathrm{CHy})$ produced a compilation of water budgets. At the EU scale, the European Environment Agency (EEA) has worked in recent years on physical water budgets at the catchment scale.

To support the creation of RBMPs, including the planning processes and the implementation of the WFD in the EU, the European Commission (EC) developed the Guidance for Water Budgeting (EC, 2015). This document focuses on the application of water budgets (balances) as a "coherent framework to crossevaluate the information on drivers, pressures and impacts on water quantity (including the coherence between water extraction and water recharge, water flows between water bodies/catchments, storage changes over time, etc.) and providing a sound basis for the quantitative management of water resources" (EC, 2015, p.6). However, the EU Guidance for Water Budgeting (EC, 2015) does not fully recognise the specificity of karstic aquifers and the water budget methodology needed for this sort of aquifer system, dominant in many Alpine and Dinaric countries of SE Europe. In recent projects that were completed in the Dinaric re-

\footnotetext{
${ }^{1}$ (http://www.fao.org/nr/aquastat/en)

${ }^{2}$ (http://www.wmo.int/pages/prog/hwrp/chy/)
} 
gion (STEVANOVIĆ \& DOKMANOVIĆ, 2015; STEVANOVIĆ et al. 2015; STEVANOVIĆ \& MARINOVIĆ, 2016), to assess the quantitative status, climatic and hydrological parameters taken from the database of the national hydrometeorological service or registered in the field during the initial characterisation of GWBs and their catchments, were compared with the historical data on water extraction (springs and wells) of delineated GWBs. Data on the groundwater levels of dug or drilled wells and their trends were also taken into consideration as controlling indicators of sustainable water use. The main component of a water budget is $\mathrm{I}_{\mathrm{ef}}$ (effective infiltration of rainfall into the ground, as aquifer's recharge). $\mathrm{I}_{\mathrm{ef}}$ fluctuates throughout the year and depends on numerous factors, such as vegetation season (interception intensity), snow and ice cover, actual deficit of soil moisture, groundwater depth, rainfall intensity, air temperature, winds and so on; however, for our analyses it was necessary to average the $\mathrm{I}_{\mathrm{ef}}$ at the annual level (long-term annual recharge, LTA). Experiences in determining $\mathrm{I}_{\mathrm{ef}}$ in Dinaric karst are also discussed by RADULOVIĆ, 2000; MILANOVIĆ, 2005; RADULOVIĆ M.M., 2012; STEVANOVIC et al. 2016. In general, dynamic (replenishable) groundwater $(G W)$ reserves in a GWB could be roughly equalised to $\mathrm{I}_{\mathrm{ef}}$. In karst terrains and aquifers, $\mathrm{I}_{\mathrm{ef}}$ can be evaluated based on the total average springs' discharge and variation of storage. In intergranular aquifers, however, another approximate parameter can be introduced based on the results of conducted field tests or modelling: potential extraction per kilometre of length of alluvial aquifer along the riverside. To determine the amount of water that can be sustainably used as exploitable groundwater reserves $\left(\mathrm{Q}_{\mathrm{expl}}\right)$, groundwater needed for dependent eco systems in the form of ecological flow $\left(\mathrm{Q}_{\mathrm{eco}}\right)$ should be subtracted from dynamic reserve $\left(\mathrm{Q}_{\mathrm{dyn}}\right)$ :

$$
\mathrm{Q}_{\text {expl }}=\mathrm{Q}_{\mathrm{dyn}}-\mathrm{Q}_{\mathrm{eco}}
$$

Therefore, the total minimal discharge of springs of one GWB could be considered the ecological flow, while the average total discharge via springs could be approximated as dynamic groundwater reserve. In order to verify the correctness of such an assessment, we can also compare the results obtained from the separation of hydrographs in which river baseflow supposedly corresponds relatively well with dynamic reserves. One of the prerequisites for such equivalency is to properly determine the boundaries of the river basin, which is not an easy task in highly karstified terrains. In terms of pressure, relevance should be given to these potentially exploitable GW reserves and the relation on annual basis between them and the total of extracted (or demanded) waters:

$$
\mathrm{P}_{\text {quant }}=\sum \mathrm{Q}_{\text {extr }} \text { vs. } \sum \mathrm{Q}_{\text {expl }}
$$

where

$\mathrm{P}_{\text {quant }}$ denotes quantitative pressure on groundwater body;

$\mathrm{Q}_{\text {extr }}$ denotes total extracted waters;

$\mathrm{Q}_{\text {expl }}$ denotes exploitable groundwater reserves.

This two-step approach is adequate for two reasons: first, it considers ecological demands, and second, in relatively waterrich countries with a small extraction of groundwater there is no need to use static water reserves, (accumulated in deeper aquifer parts as non-renewable stock), except in very rare cases (during extreme droughts) and when their rapid replenishment during periods of flooding is ensured (STEVANOVIĆ, 2015). When assessing quantitative pressure on GWB by comparing potentially exploitable and actually utilised resources, we often overlook the fact that most of the utilised water will be returned to the ground or to the water recipients. The only exception is the transfer of water over long distances out of the concerned GWB or basin. This means that if the return flow, either from the municipal sewage system or from irrigation, is in the same GWB, the ecological flow will be supported by re-infiltrated used waters. The quality of these waters is another aspect that requires attention. In order to obtain a realistic view of the potential of, and not only the actual pressure on GWB, as well as also "to be safe", the actual extraction can be replaced by projected water demands for the determined period of time.

There are several possible approaches to defining the pressure categories (at risk or not at risk) and they greatly depend on water availability. Considering the fact that almost all of the studied karstic GWB are characterised by specific yield greater than $20 \mathrm{l} / \mathrm{s} / \mathrm{km}^{2}$, and that Dinaric karst countries regularly utilise less than $5 \%$ of their water potential (FAO AQUASTAT, 2018), we may declare them as water-rich countries, and impose limits which are more restrictive than in some arid countries, where humanitarian aspects must also be considered (STEVANOVIĆ, 2018). The criterion "percentage of" should thus be adapted to local circumstances; still, wherever possible, it should not change within the same river basin. As an example, the following pressure categories and limits can be imposed in water-rich countries:

- No pressure, when GW extraction $\left(\mathrm{Q}_{\mathrm{extr}}\right)<33 \%$ of GW exploitable reserves $\left(\mathrm{Q}_{\text {expl }}\right)$;

- No pressure (but potentially under pressure ${ }^{3}$ ), when GW extraction $\left(\mathrm{Q}_{\text {extr }}\right)=33-66 \%$ of $\mathrm{GW}$ exploitable reserves $\left(\mathrm{Q}_{\text {expl }}\right)$; and

- Under pressure, when GW extraction $\left(\mathrm{Q}_{\text {extr }}\right)>66 \%$ of GW exploitable reserves $\left(\mathrm{Q}_{\text {expl }}\right)$.

\subsection{Methods of Assessing Pressure on Groundwater Quality}

At the EU level, several technical reports have been prepared for the purpose of assisting and contributing to the process of harmonisation of approaches to and procedures for pressure on water quality and risk assessment, as the report made by the Groundwater Working Group (GW WG) in 2003 (GW WG, 2003). Besides the national reports of the EU members, similar concepts were also followed during preparation of the RBMPs of large internationally shared basins, such as that of the Danube, adopted by the International Commission for the Protection of the Danube River (ICPDR) in 2010 (ICPDR, 2010) or the Sava river, adopted by the International Sava River Basin Commission (ISRBS) in 2014 (ISRBS, 2014). For the purpose of RBMP, the pressures on water quality of each of the receptors - delineated groundwater bodies (GWB) should be estimated based on groundwater vulnerability (MARGAT, 1968), hazard and risk assessment according to diffuse and point pollutant sources. In the most recent decades, vulnerability assessment of groundwater and aquifers has become a necessary tool for planning and managing groundwater

\footnotetext{
${ }^{3}$ The category "Potentially under pressure" is not recognised in WFD or EU reference application documents (CIS). However, we suggest this category in RBMPs for a pragmatic reason: to warn the decision makers and local populations that groundwater extraction must be applied with caution and coupled with systematic monitoring of its effects.
} 
resources. In combination with hazard and risk maps, vulnerability maps point to endangered areas of special significance (springs, quality water reservoirs, national and nature parks, etc.) that need to be proactively protected.

One of the objectives is to demonstrate that natural protection varies from one site to the next, and that especially vulnerable places can exist even within the same aquifer system or groundwater body. Vulnerability mapping and presentation of results in GIS is applicable to all types of rocks/aquifers, but it is especially important for karst terrains, due to their inhomogenous and anisotropic properties. The concepts of the "European approach" to mapping karst groundwater vulnerability are introduced in practice by the project COST 620 (ZWAHLEN, 2004). Therefore, the following can be distinguished: 1) methods designed for karst aquifers (e.g. EPIK method, DÖRFLIGER, 1996), and 2) methods applicable to other aquifers, with special emphasis on karst (e.g. PI method - GOLDSCHEIDER, 2005). In addition to these two, there are several other methods that are used, among the most frequent being DRASTIC (ALLER et al., 1987), and COP (VÍAS et al., 2002).

The weak point of these and many other methods that have been developed for the purpose of vulnerability assessment is the fact that empirical parameters are chosen without physical basis and established common classification (NEUKUM \& HÖTZL, 2005). Experience has shown that a specific methodology could be developed for any terrain and related aquifer systems. As such, the authors of this article developed the original SODA method, which was applied for the first time in the RBMP for the Sava River basin in Bosnia \& Herzegovina (STEVANOVIĆ \& MARINOVIĆ, 2015). Those RBMPs were adopted during 2016 at the national level under the Agency for the Sava River Basin (ASRB) for the Federation of Bosnia and Herzegovina, the Public Institution Waters of Srpska (PIWS) for the Republic of Srpska and the Government of Brčko District (GBD) for the Brčko District.

The acronym SODA comprises the following parameters:

- Parameter S - (Slope) inclination of terrain,

- Parameter O - (Overlying strata) soil, surficial strata and cover of underlying aquifer,

- Parameter D - (Depth) to the groundwater table, and

- Parameter A - (Aquifer) type of locally present aquifer.

For each of the parameters, there are weighting factors that consider local-specific circumstances and characteristics. The factors range from 1 to 10 , in such a way that smaller weighting factors correspond with the appropriate conditions, favourable for water protection, while larger numbers correspondingly raise the aquifer vulnerability. For instance, in case of parameter S, flat terrains which enable longer water retention and possible greater infiltration should be marked by higher factors than highly inclined terrains. Or in the case of A, highly permeable aquifers require a factor with a higher weighting than those that are moderately or less permeable. The index for each pixel on the map can be obtained by combining these factors for the chosen vulnerability algorithm.

After the creation of all four base layers (maps) in GIS, the final aquifer vulnerability (V) map can be completed based on different algorithms. One of them, which logically emphasises the primary importance of parameters A (Aquifer) and $\mathrm{O}$ (Overlying strata), is:

$$
\mathrm{V}=(\mathrm{S} \times 1)+(\mathrm{O} \times 3)+(\mathrm{D} \times 2)+(\mathrm{A} \times 4)
$$

Equation (3) shows that each pixel within Slope, Overlying strata, Depth and Aquifer layer was multiplied by numbers 1, 3, 2 and 4, respectively. The Vulnerability Map was then created by summarizing those new values for all four layers which are in the range from $10-100$. The selection of vulnerability classes depends on obtained values, and the ranking of indexes should be equitably balanced to avoid extremes; in other words, neither low nor highly vulnerable classes should be dominant. One of the possible categorisations is shown in Table 1.

The main anthropogenic influences on the chemical status of GWBs include two main groups: Diffuse pollution sources, and Point sources of pollution. The hazard maps (the results of possible pollution from present diffuse and point pollutants, (DALY et al., 2002) and risk maps (combination of hazards and intrinsic (natural) vulnerability of the terrain) of groundwater should be created separately because of the impossibility of performing common mathematical calculations of vector and raster data in the GIS environment. The easiest way to create a Groundwater Hazard Map based on diffuse pollution sources is to transform the CORINE land use map created jointly by the European Environment Agency and European Topic Centre Terrestrial Environment (EEA \& ETCTE) in 2018. In accordance with the legend that represents a constituent part of the CORINE 2018 map, each pixel on the map is assigned a value that indicates a type of land cover. Since land use can be one of the most important indicators of the sensitivity of water quality to pollution, a load coefficient of 0 to 1 should be appointed to each pixel on the map depending on the potential pollution hazard. These assigned values are empirical, and the largest values are commonly present in zones of mining, landfills, waste dump sites, heavy industry or irrigated areas with intensive crop production, as these can have a high impact on groundwater quality deterioration as diffuse pollution sources. For transformation of CORINE's values into load coefficients (hazard indices) some of the procedures, e.g. the one from the EU project CC-WARE (ČENČUR CURK, 2014) could be applied. In this way, a Groundwater Hazard Map after diffuse pollutants would have several hazard classes based on the ranking of the hazard indices (Table 1).

The Groundwater Hazard Map based on point pollutants has to be created separately from that for diffuse pollutants and is commonly presented as a map with circles showing the intensity of threats at their exact locations. The main input for the Hazard Map based on point pollutants is the current Population Equivalent (PE) load which reflects the equivalence between the polluting potential of an industry and a particular population, which produces the same polluting load (SPERLING \& CHERNICHARO, 2005). Each point pollutant is expressed as population equivalent load (PE load) and, depending on the PE load and according to the ratio of the minimum and maximum calculated loads, a circle of a precisely determined radius is attributed to each point pollutant. Although the main purpose of this kind of map is just a visualization of the threats, an actual hazard based on point pollutants can be represented as a ratio of the area covered by circles and the surface of a studied GWB, although such an approach always includes a high level of subjectivity.

This is why a risk assessment is much more accurate if we compare the intrinsic vulnerability and hazard from diffuse pollution sources (DALY et al. 2002). This concept includes a combination of a Groundwater Vulnerability Map and a Groundwater Hazard Map based on diffuse pollution sources: in other words, the risk of pollution will depend on both the potential diffuse pollutants and the vulnerability of the aquifers and ground- 
Table 1. One of the possible categorisations of the intrinsic aquifer vulnerability, hazard and risk after diffuse pollutants and corresponding pressures (risk) categories.

\begin{tabular}{|c|c|c|c|c|c|c|}
\hline $\begin{array}{c}\text { Aquifer (GWB) } \\
\text { vulnerability classes }\end{array}$ & Index & GW hazard classes & Index & GW risk classes & Index & $\begin{array}{c}\text { Pressures - Final Risk } \\
\text { categories }\end{array}$ \\
\hline Impervious rocks & $0-10$ & No hazard & $0-0.10$ & No risk & $<1$ & \multirow{2}{*}{$\begin{array}{l}\text { No pressure (Not at } \\
\text { risk) }\end{array}$} \\
\hline Very Low & $11-30$ & Very Low & $0.11-0.33$ & Very Low & $1-10$ & \\
\hline Low & $31-50$ & Low & $0.34-0.60$ & Low & $11-30$ & \multirow{2}{*}{$\begin{array}{c}\text { Potentially under } \\
\text { pressure } \\
\text { (Potentially at risk) }\end{array}$} \\
\hline Moderate & $51-70$ & Moderate & $0.61-0.70$ & Moderate & $31-49$ & \\
\hline High & $71-90$ & High & $0.71-0.80$ & High & $50-72$ & \multirow[t]{2}{*}{$\begin{array}{c}\text { Under pressure } \\
\text { (At risk) }\end{array}$} \\
\hline Very High & $91-100$ & Very High & $0.81-1.0$ & Very High & $73-100$ & \\
\hline
\end{tabular}

water. For example, the low degree of intrinsic groundwater vulnerability can exaggerate risk due to diffuse pollution in the same GW body. In contrast, if there are no activities in the vulnerable catchment area, the risk can be still low. The risk mapping methodology implies the multiplication of each pixel from the vulnerability map with the corresponding hazard map pixel, resulting in a proportional index of risk (i.e. Risk $=$ Vulnerability $\mathrm{x}$ Hazard) (Table 1).

In general, the first two categories could be considered as "no pressure", the following two as "potentially under pressure", and the last two as "under pressure". Depending on the $\%$ of the surface which the designated risk categories cover, each of the studied GWB could be proclaimed at risk or not. The status "conditionally under pressure" could also be applied, just in case that insufficient data regarding land use and local activities and pollutants are collected and evaluated, and that preliminary assessment is thus considered probable and not certain - meaning that it requires confirmation by way of operational GW monitoring. Data gaps and inconsistencies have become apparent in many national reports, resulting in uncertainties in the interpretation of the presented data. It is therefore common to establish a level of confidence High - Medium - Low for the assessment of groundwater status for each studied GWB.

\section{RESULTS}

Based on the platform described above, the analyses and assessment of pressures on aquifer systems have been encompassed in the Dinaric Region of SE Europe (Fig. 1).

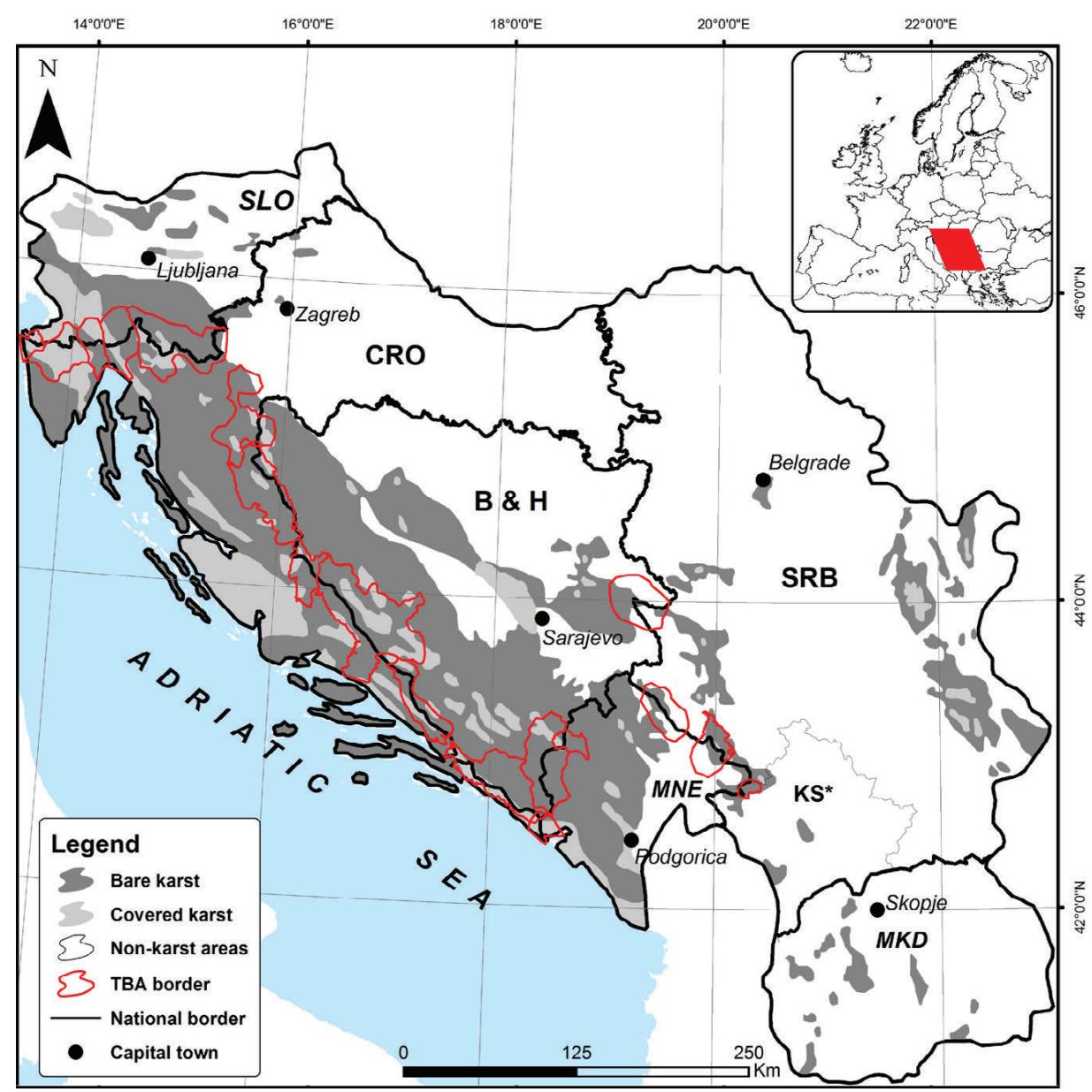

Figure 1. The distribution of karst in the former Yugoslavia (HERAK, 1972, modified) with karst transboundary aquifers (TBA). 


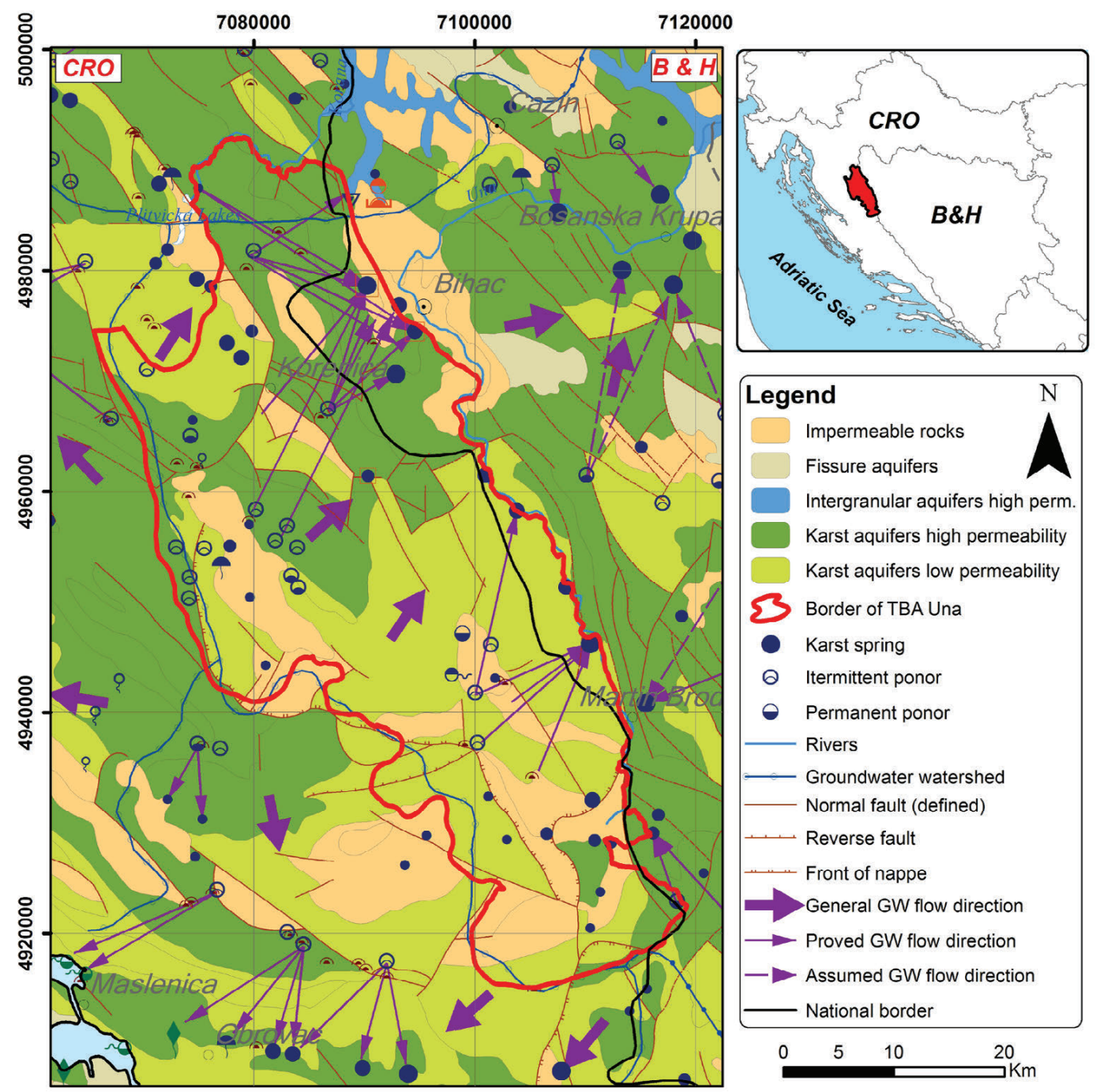

Figure 2. A hydrogeological map of the Una transboundary aquifer shared between Croatia and Bosnia \& Herzegovina (after DIKTAS database, modified).

The first example shows the outcomes of the project that has been implemented in practically the entire Dinaric region with the aim of focusing the attention of the international community on the huge but vulnerable water resources contained in karst aquifers within the Dinaric chain. DIKTAS is an acronym of the GEF (Global Environment Facility) regional project "Protection and Sustainable Use of the Dinaric Karst Transboundary Aquifer System", which was implemented in the period 2011-2015. At the regional level, the main project objectives were to facilitate equitable and sustainable utilisation and management of the transboundary water resources, and to protect the unique groundwater dependent ecosystems that characterise the Dinaric karst region from natural and man-made hazards, including climate change (STEVANOVIĆ et al. 2016). The conducted Transboundary Diagnostic Analysis (TDA) was based on substantial regional analysis and focused on selected and prioritised transboundary groundwater bodies (TGWBs), examining current and potential issues of concern. Based on five criteria (importance, representativeness, data availability, issues of concern, relevance), eight TGWBs were initially selected for detailed analysis. One of them, TGWB Una (Fig. 2), has a total area of about $1773 \mathrm{~km}^{2}$, of which $78 \%$ is karst terrain primarily composed of limestones of Mesozoic age.

The Croatian proportion of the TGWB is $1605 \mathrm{~km}^{2}$ (of which $77.5 \%$ is karst), and the $\mathrm{B} \& \mathrm{H}$ proportion is $168 \mathrm{~km}^{2}(80 \%$ is karst). The groundwater flow directions are exclusively from Croatia to $\mathrm{B} \& \mathrm{H}$, as identified by numerous dye tracing tests which traversed the boundary between the two countries (BIONDIĆ et al., 2010). The average dynamic reserves of groundwater in the TGWB Una are about $34 \mathrm{~m}^{3} / \mathrm{s}$. The minimum recorded discharge of springs is assumed to correspond to the minimum ecologically acceptable flow. This value for the springs in Croatia is $0.86 \mathrm{~m}^{3} / \mathrm{s}$

Table 2. Available and tapped (utilised for public water supply) groundwater reserves in the TBA Una.

\begin{tabular}{|c|c|c|c|c|c|c|}
\hline $\begin{array}{l}\text { Average springs } \\
\text { discharge / dynamic } \\
\text { reserves, } \mathrm{Q}_{\text {dyn }}\left(\mathrm{m}^{3} / \mathrm{s}\right)\end{array}$ & $\begin{array}{c}\text { Ecological flow }-Q_{\text {eco }} \\
\left(\mathrm{m}^{3} / \mathrm{s}\right)\end{array}$ & $\begin{array}{l}\text { Exploitable reserves } \\
\begin{array}{l}Q_{\text {expl. }}=Q_{\text {dyn }}-Q_{\text {eco }} \\
\qquad(3)=(1)-(2)\end{array}\end{array}$ & $\begin{array}{l}\text { Actually utilised } \\
\text { groundwater }\left(\mathrm{m}^{3} / \mathrm{s}\right)\end{array}$ & Water demands $\left(\mathrm{m}^{3} / \mathrm{s}\right)$ & $\begin{array}{c}\text { Ratio } \\
\text { Water demands. vs. } \\
\mathrm{Q}_{\text {expl }}(\%) \\
\text { (5) vs. (3) }\end{array}$ & Risk \\
\hline 1 & 2 & 3 & 4 & 5 & 6 & 7 \\
\hline 34 & 5.81 & 28.19 & 0.685 & 1.32 & $4.7 \%$ & No \\
\hline
\end{tabular}




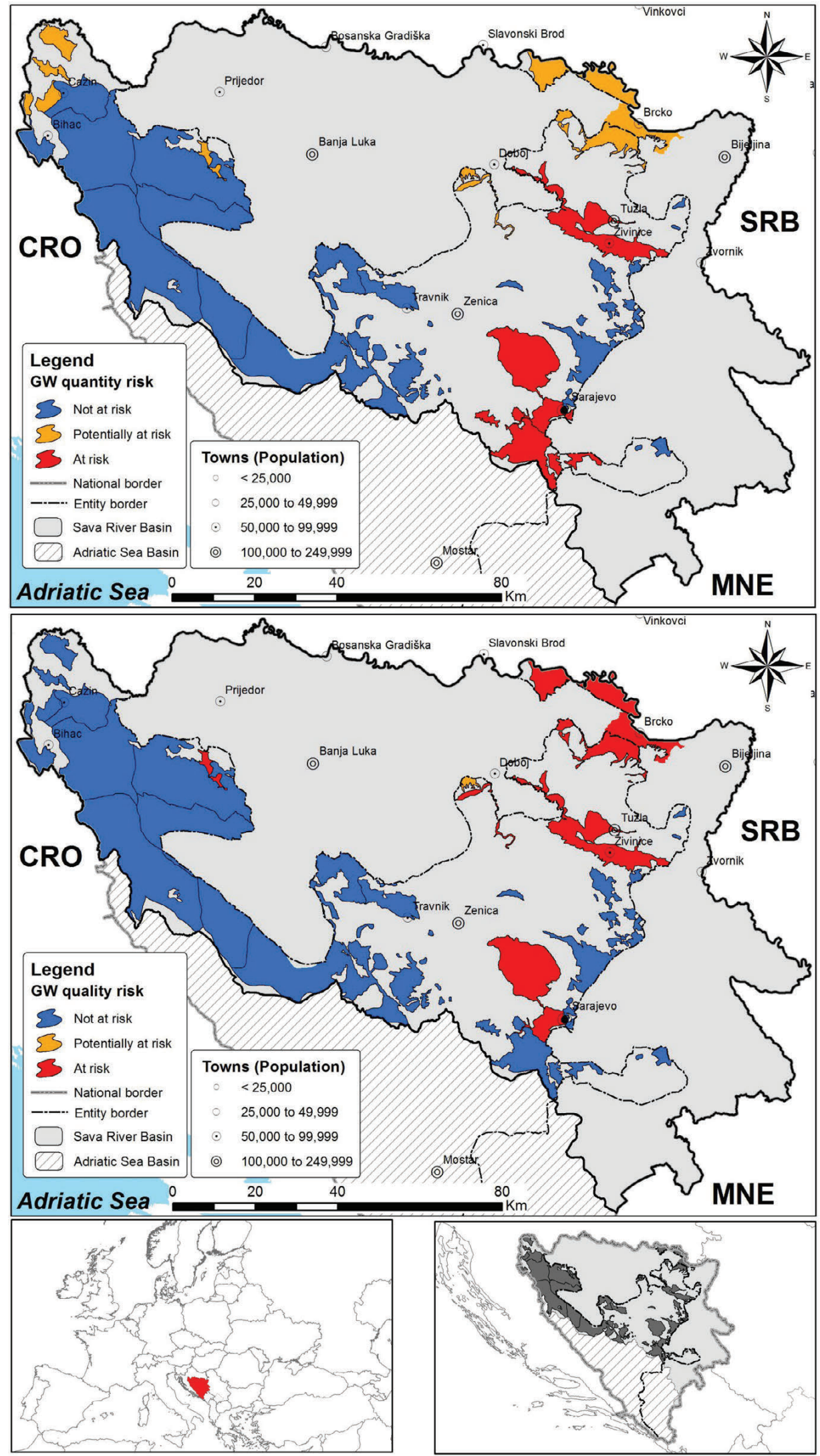

Figure 3. Map showing the categories of groundwater quantitative and qualitative risks of GWBs delineated in the Sava River basin in the territory of Federation of Bosnia \& Herzegovina (FB\&H) (according to ASRB, 2016).

and in $\mathrm{B} \& \mathrm{H}$ it is $4.95 \mathrm{~m}^{3} / \mathrm{s}$, for the total of $5.81 \mathrm{~m}^{3} / \mathrm{s}$ (Table 2). The tapped amount of groundwater used for the water supply in B\&H is $0.52 \mathrm{~m}^{3} / \mathrm{s}$. In Croatia, it is about $0.165 \mathrm{~m}^{3} / \mathrm{s}$, for the total of 0.685 $\mathrm{m}^{3} / \mathrm{s}$. This includes industry and the inhabitants connected to centralised water supply systems. It is estimated that approximately $35-40 \%$ of the inhabitants in the area are not served by these systems and instead obtain their drinking water from smaller local (rural) waterworks, individual wells or smaller 

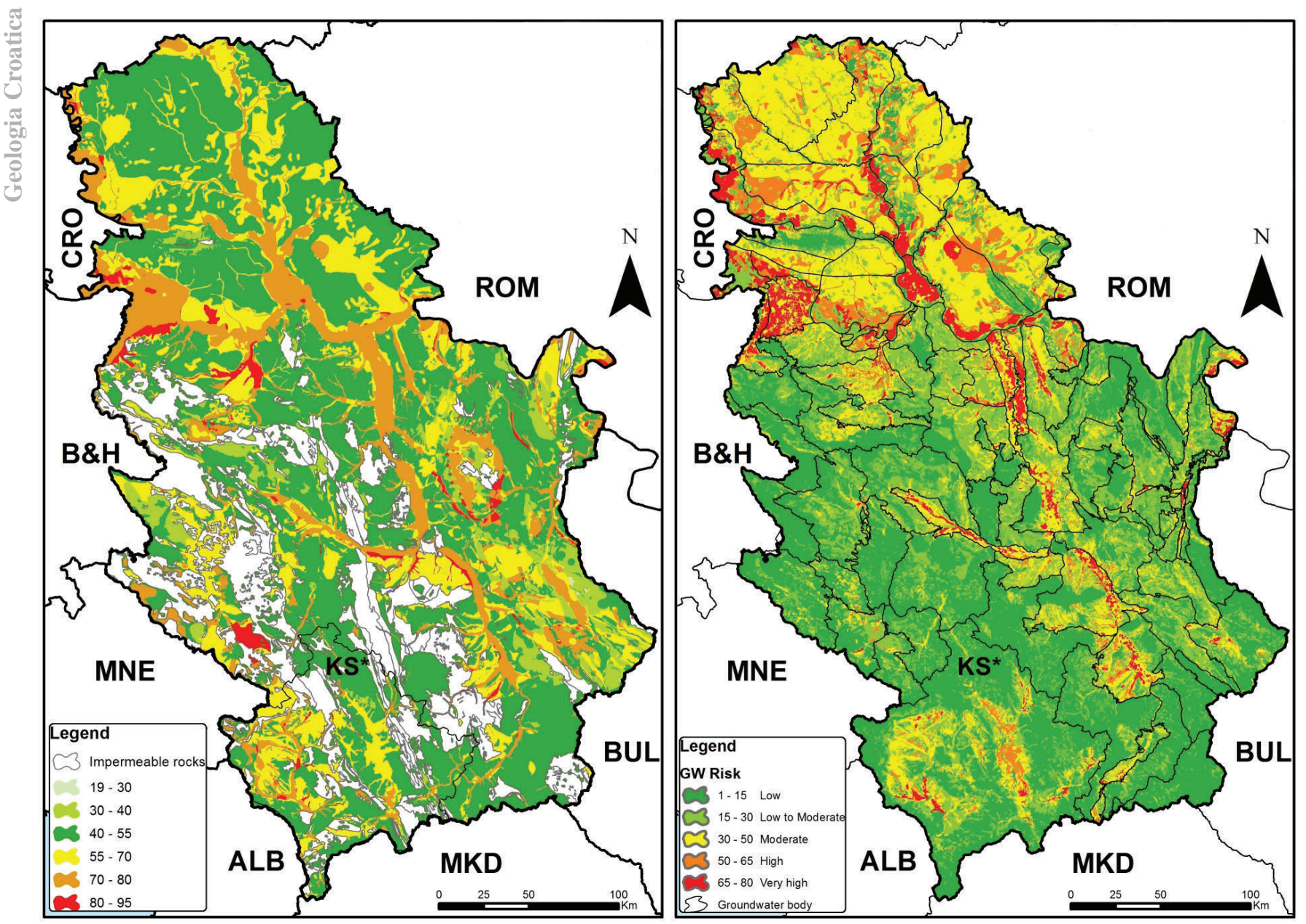

Figure 4. An aquifer vulnerability map of Serbia and Kosovo* (left) (MILANOVIĆ et al., 2010, modified); and the groundwater risk map of Serbia and Kosovo*(right) (STEVANOVIĆ \& MARINOVIĆ, 2016).

tapped springs. By connecting these consumers to the municipal systems and envisaging some $20 \%$ of additional water for covering the future population and tourism growth and industrialisation, the total water demands for the next 25 years may increase to $1.32 \mathrm{~m}^{3} / \mathrm{s}$.

The comparison of water demands and exploitable reserves shows that TGWB Una is far from being at risk when it comes to water quantity, and that sustainable development of the GWB can continue for many decades. Even during drought seasons, water demands are much lower than the minimal discharge of springs as a guaranteed ecological flow (19.1\%). Nevertheless, detailed interdisciplinary scientific investigations and measures should be carried out in order to obtain harmonious, reliable and sustainable development in a very complex, valuable and vulnerable ecological and social Dinaric karst system, taking into account an extreme stress on the Dinaric karst water resources (BONACCI, 2014). The corresponding methodology for quantitative pressures and risks has been applied in the River Basin Management Plan for the WB of the Sava River basin in the territory of the Federation of Bosnia \& Herzegovina (FB\&H). The criteria for the risk categories and limits are as follows:

- No pressure (Not at risk), when GW extraction $\left(\mathrm{Q}_{\text {extr }}\right)<33$ $\%$ of GW exploitable reserves;

- Potentially under pressure (Potentially at risk), when GW extraction $\left(\mathrm{Q}_{\text {extr }}\right)=33-66 \%$ of GW exploitable reserves; and

- Under pressure (At risk), when GW extraction $\left(\mathrm{Q}_{\text {extr }}\right)>66$ $\%$ of GW exploitable reserves.
The analyses of FB\&H, as one of the two existing entities in Bosnia \& Herzegovina, is very important because the majority of the delineated GWBs are of transboundary character and are shared with another entity - the Republic of Srpska and neighbouring Croatia. Out of 17 delineated GWBs, only three are completely internal. Out of these $17 \mathrm{GWBs}, 11$ are not at risk (2/3), three are potentially at risk, while three were found to be at risk (ASRB, 2016, Fig. 3).

The analyses of diffuse and point pollutants in the same river basin have resulted in the assessment that $75 \%$ of the GWBs are not at risk, that $20 \%$ actually are at risk, and that just $5 \%$ are potentially at risk (Fig. 3). As a result of the application of the SODA method, the classes of moderate to high vulnerability prevail and cover $68,6 \%$ of the Sava River basin in the territory of FB\&H, while very high vulnerability characterises $4,86 \%$ of the basin.

Several "strategic" projects for groundwater resource evaluation have been conducted in Serbia between 2008 and 2012. One of them evaluated the actual status and needs for improvement of groundwater monitoring, and Serbia became one of the first countries in Europe that created an Aquifer Vulnerability Map that covered the entire national territory (MILANOVIĆ et al., 2010). Later, creation of an Aquifer Vulnerability Map for the entire country became a requirement for all EU member countries as well as EU candidate countries especially when coping with the Water Framework Directive. This regional map was created in GIS, and its details were adjusted to be in accordance with a scale of 1:500.000 (MILANOVIĆ et al., 2010, Fig. 4). According to the Aquifer Vulnerability Map, the Moderate vulnera- 
bility class has the widest distribution in Serbia $(46 \%$ of the country).

Based on the vulnerability map and the hazard map (according to diffusing pollutants), a risk map covering the entire territory of Serbia and Kosovo* was also created (Fig. 4). The risk map includes three main categories: 1 . The zones with a very high risk of groundwater pollution are distributed around the main urban agglomerations, industrial and agricultural areas, and along river valleys with busy traffic corridors. 2 . Moderate $(43 \%)$, and 3 . Low to Moderate $(22 \%)$ categories have the widest distribution in Serbia. Concerning transboundary water management, the aquifers under greater risk of pollution are located in the SE - Timok valley (near Bulgaria), the West Lower Drina valley (near Bosnia \& Herzegovina) and the Danube valley (near Croatia).

The transboundary GWB Prokletije is shared by Montenegro and Albania (Fig. 5). The surface located in Montenegro is estimated at $70 \mathrm{~km}^{2}$. This is a highly mountainous terrain where the highest peaks reach $2190 \mathrm{~m}$ a.s.l. The total drainage of karst aquifers in Montenegro is on average c. $5 \mathrm{~m}^{3} / \mathrm{s}$, more than half of which is the discharge of the Alipašini springs ( $\mathrm{Q} \min / \mathrm{max}=$ $2.5-7 \mathrm{~m}^{3} / \mathrm{s}$, RADULOVIĆ, 2000). This is a typical case of exploitable reserves greatly exceeding the actual water extraction which is less than $1 \%$ of the reserves. The GWB would not be at risk even if water demands experienced significant growth.

The application of SODA showed a relatively high aquifer vulnerability: the class „Moderate to High“ covers approximately $60 \%$ and „Very High" around $10 \%$ of the surface area (Fig. 5), but the TGWB is not at risk as there are no industrial polluters on either side of the border. However, diffuse sources of pollution which include agricultural areas, local landfills, the local road network and small villages not connected to a sewage system, should be closely monitored and the environmental situation should be improved to prevent water quality deterioration.

\section{DISCUSSION}

The objective of this article is to present a methodology that could facilitate the process of assessing the quantitative and qualitative status of groundwater, especially on a "regional scale", meaning at the level of a country or a large river basin. A more detailed and advanced methodology is recommended for smaller river basins and catchments.

For instance, the Danube RBMP (ICPDR, 2010) has only evaluated transboundary groundwater bodies larger than 1000 $\mathrm{km}^{2}$, while detailed delineation of groundwater bodies is left to the RBMP of each country that belongs to the basin. The EU WFD has also set forth a logical concept "from the larger to the smaller river basin", and thus the plan for larger basins should contain data of a more general nature, while the degree of detail should increase with the transition to smaller river basins.

The problem often faced by hydrogeologists preparing RBMPs, especially in developing or "transitional" countries, is the lack of data on groundwater distribution and regime. For example, in Montenegro - a country abundant in groundwater only one karst spring and a few piezometers are observed on a permanent basis. In Serbia, 375 currently observed piezometers are located in 41 out of the totally delineated 153 GWBs (STEVANOVIĆ \& DOKMANOVIĆ, 2015). The RBMP for the Danube (ICPDR, 2010) indicates the main components of the methodologies that were used to assess the risk of failure to achieve good chemical status. These are: the available monitoring data on water quality, data on existing pressures and possible impacts, data on the overlying strata of the groundwater bodies, and the corresponding vulnerability of the aquifer. It should be noted that risk assessment methods are rather country-specific and range from using combinations of the afore-mentioned data sets to focus on interpreting water quality data.

How to fill the gaps in the knowledge of GWBs and aquifer systems and apply the proposed methodology? In many cases it
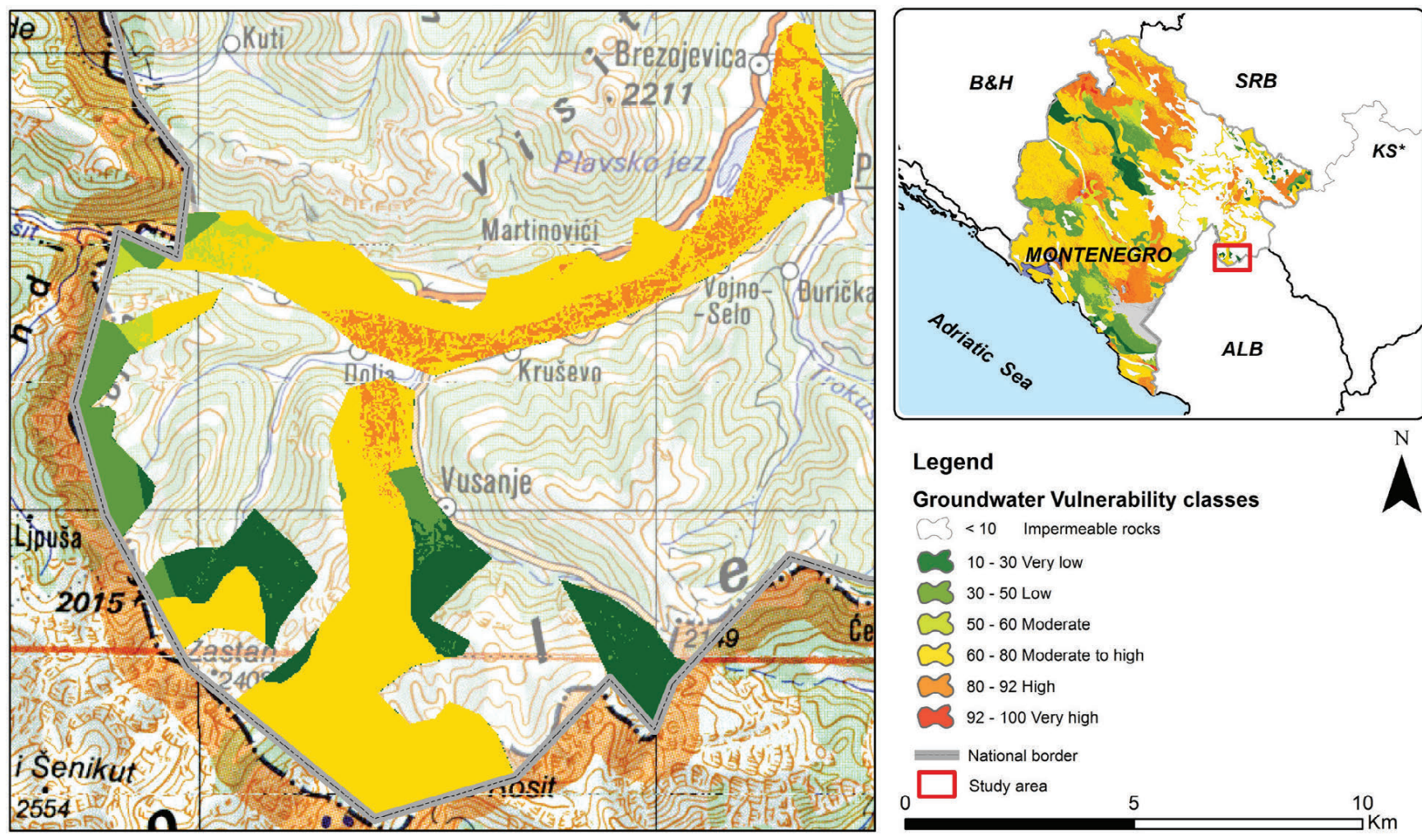

Figure 5. The vulnerability map of Prokletije transboundary GWB. 

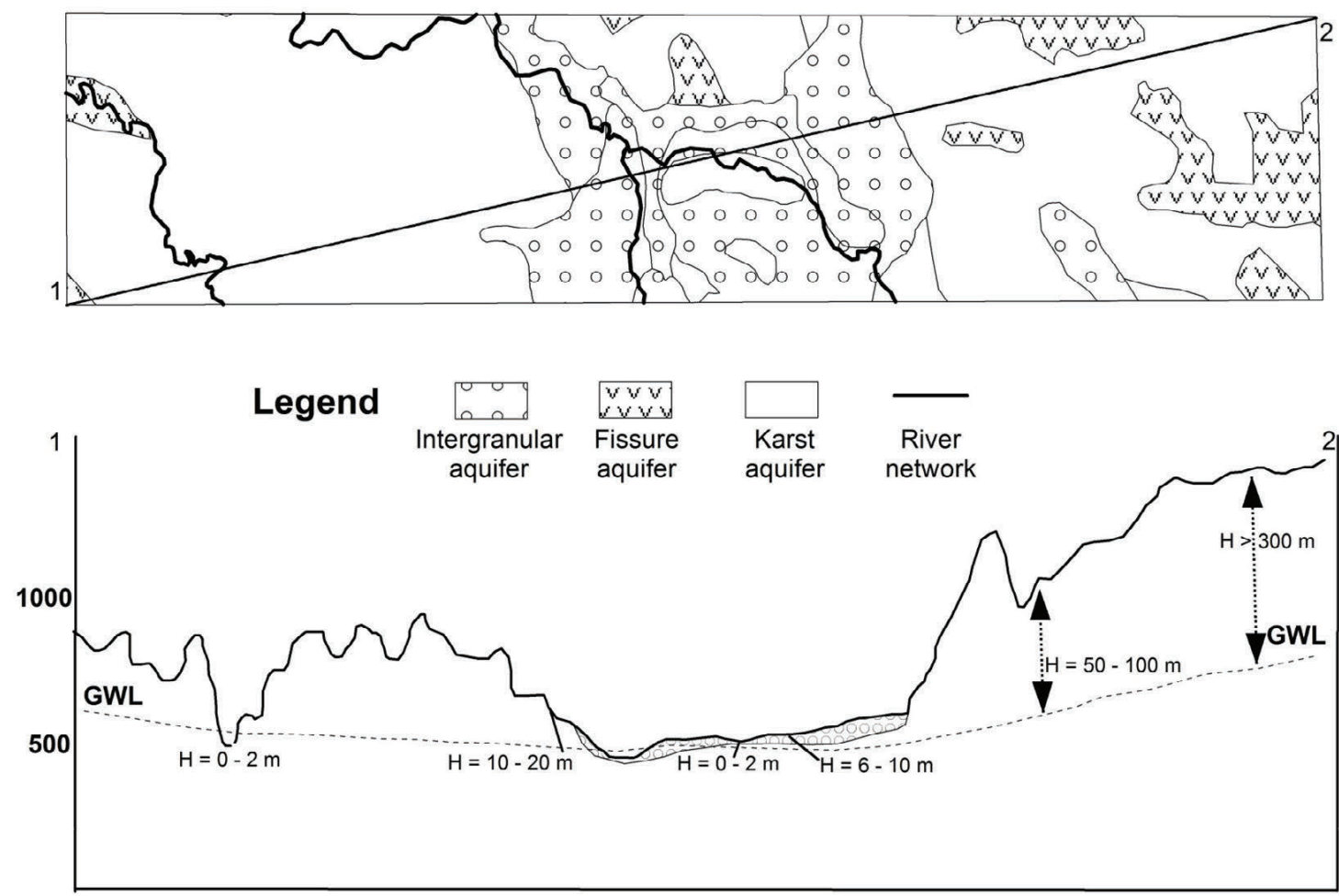

Figure 6. Cross-section 1-2 present an example of the assessment of depth (H) to groundwater table (GWL).

will be necessary to approximate some of the parameters, or to average the values of some sporadically undertaken field tests. For example, when creating a Vulnerability Map using the recommended SODA method, it is difficult to collect precise data on the "Depth" parameter (depth to the groundwater table) at the surface of the studied GWBs. To overcome this gap, one might take into consideration the elevation of drainage points (springs) or erosional bases (rivers) towards which groundwater flows are oriented. In the former case, in well-developed karst, a rough approximation includes interpolated elevations within the interior of the catchments, in a way that is similar to that shown on Fig. 6 . In the case of an alluvial aquifer located closer to a riverbed as an erosional base, groundwater tables are shallower and can be approximated in a similar way (Fig. 6). Although the latter is a concept that generalizes the process of determining the depth to the groundwater table in alluvial aquifers in cases when there are no sufficient piezometers or wells, this simplified concept is the only way to approximate the depth to the groundwater table.

The problem of data shortage could be recompensed by additional hydrogeological and environmental surveys, at least at designated problematic locations. Remote sensing could support mapping of aquifer systems. If discharge data for the largest springs is missing, a series of measurements in high/low periods could provide basic ideas on the presence and regime of groundwater. Similarly, hydrochemical in situ prospection and a series of chemical analyses of micro-constituents may enable assessment or confirmation of the water quality and trends. The preparation of RBMPs of large basins usually takes between $1.5-3$ years, which is sufficient time to organise at least annual monitoring at the main water points (springs or boreholes). Furthermore, with support of hydrological and/or hydrodynamic modelling, this data could be used in forecasting the effects of climate changes or possible artificial interventions (STEVANOVIĆ, 2015).

The existing and most frequently applied concept to assess pressure on groundwater quantity is based on water table obser- vation. In many cases, significant water table depletion is a clear indicator of over-extraction of groundwater and a sign of pressure. However, in highly dynamic aquifers such as those that are karstic, even a large amplitude of water table fluctuation could be the result of temporarily changed natural conditions and might not necessarily be caused by water abstraction. It is therefore much more accurate to assess pressure on GWBs by evaluating water budget elements on a multiannual or annual basis.

Efficient technologies offered by GIS software packages enable the creation of a simple database, quick calculation, and (visually) well presented spatial parametrisation. The three steps of GIS mapping have proven to be the most efficient way of assessing and visualising the groundwater distribution and quality status. Although mainly of regional character, obtained data and categorisation of GWB by use of the suggested methodology support the following: 1. Foundation for a more detailed analyses and RBMPs of smaller basins; 2. Organisation of groundwater monitoring; 3. Definition of a programme of measures for groundwater protection; 4. Sustainable development of aquifer systems and water sources; 5. Optimisation of spatial planning and land use; 6. Creation of early warning and information exchange systems as part of transboundary water management.

RBMP and its Programme of Measures (PoM) could serve as a starting point for planning more detailed research, which may include modelling of different water use scenarios, forecasting of pollution trends, climate change impacts. Although not recommended for concrete projects such as selecting landfill sites, choosing new road paths or finding appropriate locations for industrial objects, the results obtained could also be used as an initial supportive tool.

Groundwater monitoring should be based on the results of the groundwater assessment within the RBMP and especially created vulnerability / hazard / risk maps, which should indicate prioritised "hot spots". The organisation of monitoring should include: 1. Selection of monitoring sites as part of a permanent network; 
Table 3. Assessment of pressures on groundwater quantity and quality for studied groundwater bodies.

\begin{tabular}{|c|c|c|c|c|c|c|}
\hline Groundwater body & $\begin{array}{l}\text { Water demands } \\
\text { vs. } Q_{\text {expl }}(\%)\end{array}$ & $\begin{array}{l}\text { Pressure on } \\
\text { GW quantity }\end{array}$ & Vulnerability & Hazard & Risk & Pressure on GW quality \\
\hline TGWB Una (B\&H/CRO) & 4.7 & No & N/A & $\mathrm{N} / \mathrm{A}$ & $\mathrm{N} / \mathrm{A}$ & $\mathrm{N} / \mathrm{A}$ \\
\hline $\begin{array}{c}\text { GWBs in Sava River } \\
\text { basin of B\&H }\end{array}$ & - & $\begin{array}{c}11 \text { GWBs NR } \\
3 \text { GWBs PR } \\
3 \text { GWBs R }\end{array}$ & $\begin{array}{l}\text { Mostly Moderate and } \\
\text { Moderate to High }\end{array}$ & Low to Moderate & Low to Moderate & $\begin{array}{c}12 \text { GWBs NR } \\
1 \text { GWB PR } \\
4 \text { GWBs R }\end{array}$ \\
\hline $\begin{array}{c}\text { TGWB Prokletije } \\
\text { (Montenegro-Albania) }\end{array}$ & 1 & Not at risk & Moderate to High & Low & Low & Not at risk \\
\hline Serbia & - & $\begin{array}{c}71 \text { GWBs NR } \\
12 \text { GWBs PR } \\
8 \text { GWBs R }\end{array}$ & Mostly Moderate & Mostly Moderate & $\begin{array}{l}\text { Mostly Low to } \\
\text { Moderate Risk }\end{array}$ & $\begin{array}{c}57 \text { GWBs NR } \\
31 \text { GWBs PR } \\
3 \text { GWBs R }\end{array}$ \\
\hline
\end{tabular}

NR - Not at Risk; PR - Potentially at Risk; R - At Risk; N/A - Not Applicable (not discussed in this paper).

2. Selection of the type of monitoring - surveillance or operational (after EU WFD) and 3. Definition of monitoring frequency.

BONACCI (2014) states that the complex, valuable and vulnerable ecological and social Dinaric karst system requires technical, social, economic, environmental, and cultural measures in water resources management. The results could support such a proposed interdisciplinary approach and measures, but also be useful for educational purposes and local technical capacity building. Wider promotion of RBMPs may also help decentralise the water sector and get local capacities more involved, especially those from areas indicated to be under various kinds of threats and risks. Visualised results (maps, statistics) and their promotion through media may also help raise public awareness concerning the importance of saving and protecting water and the environment.

The examples from Bosnia \& Herzegovina, Montenegro and Serbia show that the suggested methodology has been applied with success. The examples presented confirm that pressure on groundwater quantity remains low (Table 3); however, the risk of contaminating most of the evaluated aquifer systems does exist and preventive systematic protection, along with monitoring, should thus be applied in the Dinaric region.

Some of the methods presented for assessing pressure on GWBs are novel, while most are commonly used, albeit slightly adapted to the specific circumstances dictated by the presence of numerous karst aquifers. Consequently, limits i.e. the percentages used to classify GWBs as belonging to one group of risks or another are modified accordingly.

\section{CONCLUSIONS}

As an invisible but essential resource, groundwater is utilised globally for a potable water supply. Assessing its distribution, status and the pressures on water quantity and quality is one of the main tasks of the River Basin Management Plans introduced by EU WFD as an obligation to Member States. Although it requires work by professional hydrogeologists, the assessment procedures and results obtained should be applicable and also understandable to a wider audience, as well as water managers and practitioners.

Considering the complexity of groundwater, the methodology for assessing its status can be very demanding and often difficult to implement. Reliable and precise information requires systematic hydrogeological and multidisciplinary field surveys, long-term monitoring, many in situ tests, and above all significant funds and teams of professionals to undertake the work. However, for an initial assessment on a regional scale (large basins or at a country level), some simple procedures as suggested here and the use of GIS software may be sufficient.
Successful application of this methodology is confirmed by the following:

- The RBMPs for the Sava River in the territories of two entities of B\&H and the Brčko District, prepared by Eptisa and Hydroplan supported by the current authors, have been approved and implemented.

- In Serbia, there is undergoing expansion of the National Groundwater Monitoring Network which is actually maintained by the Hydrometeorological Institute of Serbia based on the programme prepared by local experts. During $2017-2019$, operational monitoring covered an additional $50 \mathrm{GWBs}$, ensuring that more than half of the total of the delineated GWBs in the country are currently under observation and that the percentage would increase even further. The selection of monitoring sites and prioritisation of the GWBs is fully based on the findings of the Risk Analysis and Maps.

- Similarly, the first group of 30 piezometers for continual monitoring of groundwater have been installed across Montenegro at the most critical hot spots identified from an environmental point of view following the results obtained by this methodology in the RBMP.

- Due to the successful results of the DIKTAS project and the previously created water management platform, the second phase of this transboundary project is under preparation. It will focus mainly on the water management infrastructure and the data exchange mechanism between the respective countries of the Dinaric region.

Finally, creating a foundation for more detailed analyses and preparing the RBMPs of smaller basins, organising groundwater monitoring, and raising public awareness of the importance of sustainable water use and protection are just some of the advantages of the proper application of this methodology.

\section{ACKNOWLEDGMENT}

The authors would like to express their gratitude to the anonymous reviewers for their careful review and useful comments.

\section{REFERENCES}

ALLER, L., BENNET, T., LEHR, J., PETTY, R. \& HACKETT, G. (1987): DRASTIC: A standardized system for evaluating ground water pollution potential using hydrogeologic settings.- Chicago, Illinois, U.S: EPA

ASRB (2016): Sava River Basin Management Plan in Federation of B\&H, Sarajevo (Available at: www.voda.ba)

BEDELL, R.L., JR. (1995): GIS for the Geosciences.- Sparks, Nevada, USA: Homestake Mining Company.

BIONDIĆ, B., BIONDIĆ, R. \& MEAŠKI, H. (2010): The conceptual hydrogeological models of the Plitvice Lakes.- Geologia Croatica, 63/2, 195-206. doi: 10.4154/ gc. 2010.17 
BONACCI, O. (1987): Karst Hydrology; with special reference to the Dinaric Karst.Springer-Verlag, Berlin.

BONACCI, O. (2014): Karst Hydrogeology/Hydrology of Dinaric Chain and Isles.- Environ. Earth. Sci., 74, $37-55$ (2015). doi: 10.1007/s12665-014-3677-8

BURKE, J.J. \& MOENCH, H.M. (2000): Groundwater and society: Resources, tensions and opportunities [Special edition of DESA and ISET].- New York: UN public. st/ esa/265

ČENČUR CURK, B. (2014): CC-WARE Mitigating vulnerability of water resources under climate change, WP-3, Annual Report.

CHANG, K.T. (2008): Introduction to Geographical Information Systems.- New York, McGraw Hill.

CUSTODIO, E. (1992): Hydrogeological and hydrochemical aspects of aquifer overexploitation. [Selected Papers of IAH], vol. 3, Verlag Heinz Heise, 3-27.

CVIJIĆ, J. (1893): Das Karstphänomen. Versuch einer morphologischen Monographie.Geographischen Abhandlung, Wien, V(3), 218-329.

DALY, D., DASSARGUES, A., DREW, D., DUNNE, S., GOLDSCHEIDER, N., NEALE, S., POPESCU I. C. \& ZWAHLEN, F. (2002): Main concepts of the "European approach" to karst-groundwater-vulnerability assessment and mapping.- Hydrogeology Journal, 10/2, 340-345. doi:10.1007/s10040-001-0185-1

DÖRFLIGER, N. (1996): Advances in karst groundwater strategy using artificial tracer tests analysis and multiattribute vulnerability mapping (EPIK method).- Unpubl. PhD Thesis, University of Neuchatel, Switzerland, $308 \mathrm{p}$.

EC (2000): Directive 2000/60/EC of the European Parliament and of the Council of 23 October 2000 establishing a framework for community action in the field of water policy.- Off. J. Eur. Communities 2000, Brussels.

EC (2006): Directive 2006/118/EC of the European Parliament and of the council of 12 december 2006 on the protection of groundwater against pollution and deterioration.- Off. J. Eur. Communities 2006, Brussels.

EC (2007): Common implementation strategy for the Water Framework Directive (2000/60/EC). Guidance Document No. 15, Guidance on Groundwater Monitoring, Brussels EC (2009) Common implementation strategy for the Water Framework Directive (2000/60/EC). Guidance Document No. 18, Guidance on Groundwater Status and Trend Assessment, Brussels.

EC (2015): Common implementation strategy for the Water Framework Directive (2000/60/EC). Guidance Document No. 34, Guidance document on the application of water balances for supporting the implementation of the WFD, Brussels.

ECKSTEIN, Y. \& ECKSTEIN, G.E. (2005): Transboundary aquifers: Conceptual models for development of international law.- Ground Water, 43/5, 679-690. doi: 10.1111/j.1745-6584.2005.00098.x

EEA \& ETCTE (2018): CORINE Land Cover 2018. Retrieved from https://land.copernicus.eu/pan-european/corine-land-cover/clc2018

ESRI (Environmental Systems Research Institute) (2003): Spatial data standards and GIS interoperability. ESRI White Paper [online]. Available at http://www.esri.com/library/whitepapers/pdfs/spatial-data-standards.pdf

FAO AQUASTAT (2018): website, available at: www.fao.org/nr/aquastat/

FORD, D. \& WILLIAMS, P. (2007): Karst Hydrogeology and Geomorphology.Chichester: John Wiley \& Sons Ltd, The Atrium, Southern Gate, 562 p. doi: 10.1002/9781118684986

GBD (2016): Sava River Basin Management Plan in Brčko Distrikt, draft version, Brčko (Available at: www.bdcentral.net)

GOLDSCHEIDER, N. (2005): Karst groundwater vulnerability mapping: application of a new method in the Swabian Alb, Germany.- Hydrogeology Journal, 13/4, 555-565. doi: 10.1007/s10040-003-0291-3

GW WG (2003): WFD Pressures and Impacts Assessment Methodology: Guidance on pressures and impacts methodology. Paper by the Working Group on Groundwater and Working Group on Characterisation and Reporting. Guidance document no. GW4. WFD Ireland.

GWP / INBO (2012): The handbook for integrated water resources management in transboundary basins of rivers, lakes and aquifers. Paris (https://www.inbo-news.org/ IMG/pdf/MGIREB-UK-2012-2.pdf)

HERAK, M. (1972): Karst of Yugoslavia.-In: HERAK, M. \& SPRINGFIELD, V.T. (eds.): Karst: important karst regions of the Northern Hemisphere. Amsterdam: Elsevier. $25-83$.

ICPDR (2010): Danube River Basin Management Plan, Vienna Austria, www.icpdr.org

ISRBS (2014): Sava River Basin Management Plan, Zagreb, Croatia, www.savacommisison.org

MARGAT, J. (1968): Vulnerabilité des nappes d'eau souterraine a la pollution [Groundwater Vulnerability to Contamination ].- Orleans: Bases de la cartographie (Doc.) 68 SGC 198HYD, BRGM

MARGAT, J. (1992): The overexploitation of aquifers. [Selected Papers of IAH], vol. 3, 29-40, Verlag Heinz Heise.

MARGAT, J. \& VAN DER GUN, J. (2013): Groundwater Around the World: A Geographic Synopsis. London: CRC Press. doi: 10.1201/b13977

MEINZER, O.E. (1920): Quantitative methods of estimating groundwater supplies.- Bull. Geological Society of America, 31, 329-338.

MIJATOVIĆ, B. (1984): Hydrogeology of the Dinaric Karst. Vol. 4. Hannover: International Association of Hydrogeologists, Heise.
MILANOVIĆ, P. (2005): Water potential in south-eastern Dinarides.-In: STEVANOVIĆ, Z. \& MILANOVIĆ, P. (eds.): Water Resources and Environmental Problems in Karst CVIJIĆ 2005, Belgrade, Faculty of Mining and Geology, 249-257.

MILANOVIĆ, S., STEVANOVIĆ, Z., ĐURIĆ, D., PETROVIĆ, T. \& MILOVANOVIĆ, M. (2010): Regionalni pristup izradi karte ugroženosti podzemnih voda Srbije nova metoda "IZDAN" [Regional approach in creating groundwater vulnerability map of Serbia - A new ,IZDAN" method - in Serbian].-In: Proceedings of the XV Serbian Geological Congress Belgrade, 585-590.

NEUKUM, C. \& HÖTZL, H. (2005): Standardisation of vulnerability map.- In: STEVANOVIĆ, Z. \& MILANOVIĆ, P. (eds.): Water Resources and Environmental Problems in Karst CVIJIĆ 2005, Belgrade, Faculty of Mining and Geology, 11-19.

PIWS, (2016): Sava River Basin Management Plan in the Republic of Srpska, draft version, Bijeljina (Available at: www.voders.org)

PURI, S. \& AURELI, A. (2005): Transboundary aquifers: a global program to asses, evaluate, and develop policy.- Ground Water, 43/5, 661-668. doi: 10.1111/j.17456584.2005.00100.x

PURI, S. \& STRUCKMEIER, W. (2010): Aquifer resources in a transboundary context: a hidden resource? Enabling the practitioner to 'see it and bank it' for good use.- In: EARLE, A. JÄGERSKOG, A. \& ÖJENDAL, J. (eds.): Transboundary water management: principles and practice, 73-90. London: Earthscan.

RADULOVIĆ, M. (2000): Hidrogeologija karsta Crne Gore [Karst hydrogeology of Montenegro].- Podgorica: Geological Survey of Montenegro.

RADULOVIĆ, M.M. (2012): Višeparametarska analiza prihranjivanja karstne izdani na primerima iz sliva Skadarskog jezera [Multi-parameter analysis of groundwater recharge in karstic aquifer - case examples from the Skadar Lake basin].- Unpubl. $\mathrm{PhD}$ Thesis, University of Belgrade, Belgrade, Serbia.

SPERLING, M.V. \& CHERNICHARO, C. (2005): Biological Wastewater Treatment in Warm Climate Regions, vol. 1; IWA Publishing, London, UK, ISBN 978-1-84339$002-2$.

STEVANOVIĆ, Z. (2015): Characterization and engineering of karst aquifers.- Switzerland: Springer International Publishing.

STEVANOVIĆ, Z. (2018): Karst aquifers in the arid world of Africa and Middle East: Sustainability or humanity?- In: YOUNOS, T., SCHERIBER, M., KOSIČ FICCO, K. (eds.): Karst Water Environment: Advances in Research, Management and Policy. The Handbook of Environmental Chemistry, vol. 68, Springer, Cham, 1-43.

STEVANOVIĆ, Z. (2019): Karst waters in potable water supply: a global scale overview.Environmental Earth Science. Springer, 78, 662. doi: 10.1007/s12665-019-8670-9

STEVANOVIĆ, Z. \& DOKMANOVIĆ, P. (2015): Creation of new extended groundwater monitoring network of Serbia.- Unpublished manuscript, Department of Hydrogeology, Faculty of Mining and Geology, University of Belgrade, Serbia.

STEVANOVIĆ, Z. \& MARINOVIĆ, V. (2015): River Basin Management Plan for Sava River in Federation of B \& H, Volume 4 Groundwater. Technical documentation of the IPA Project "Strengthening Capacity in Water Sector of Bosnia \& Herzegovina".- Sarajevo, Bosnia \& Herzegovina. Eptisa \& Hydroplan.

STEVANOVIĆ, Z., MARINOVIĆ, V., MERDAN, S., SKOPLJAK, F. \& JOLOVIĆ, B. (2015): Koncept izrade hidrogeoloških podloga za planove upravljanja rečnim slivovima [Conception of creating basic documents in hydrogeology for River Basin Management Plans].- In: Proceedings of $1{ }^{\text {st }}$ Geological Congress of Bosnia \& Herzegovina Tuzla, Bosnia \& Herzegovina: Geological Society of Bosnia and Herzegovina, Tuzla, 150-151.

STEVANOVIĆ, Z. \& MARINOVIĆ, V. (2016): The role and importance of hydrogeology in the creation of river basin management plans at a regional scale.- In: Proceedings of the IWA Specialist Groundwater Conference, Belgrade: Institute for the Development of Water Resources “Jaroslav Cerni”, 180-186.

STEVANOVIĆ, Z., KUKURIĆ, N., PEKAŠ, Ž., JOLOVIĆ, B., PAMBUKU, A., \& RADOJEVIĆ, D. (2016): Dinaric karst aquifer - One of the world's largest transboundary systems and an ideal location for applying innovative and integrated water management.- In: STEVANOVIĆ, Z., KREŠIĆ, N. \& KUKURIĆ, N. (eds.): Karst Without Boundaries. London: CRC Press/Balkema, EH Leiden; Taylor \& Francis Group, 3-25.

UNGA and INTERNATIONAL LAW COMMISSION (2008): The Law of Transboundary Aquifers.

VÍAS, J.M., ANDREO, B., PERLES, M.J., CARRASCO, F., VADILLO, I. \& JIMÉNEZ, P. (2002): Preliminary proposal for contamination vulnerability mapping in carbonate aquifers.- Karst and Environment, 75-83.

WISE GIS (2016): Guidance on the reporting of spatial data to WISE. (http://cdr.eionet. europa.eu/help/WFD/WFD_521_2016/GISGuidance/WISE_GISGuidance.pdf)

WMO, Commission for Hydrology. (http://www.wmo.int/pages/prog/hwrp/chy/)

WORBOYS, M. \& DUCKHAM, M. (2004): GIS: a computing perspective. Boca Raton: CRC Press.

WORLD WATER COUNCIL (2010): Fact Sheet: Transboundary Water Security. Marseille: 6th World Water Forum Kick-Off.

ZWAHLEN, F. (2004): Vulnerability and risk mapping for the protection of carbonate (karst) aquifers.- Luxembourg: COST Action 620, Office for Official Publications of the European Communities. 